\title{
25
}

\section{THE NETHERLANDS \\ From the first science information officers to the Dutch Research Agenda}

\author{
Anne M. Dijkstra, Frans van Dam \\ and Maarten van der Sanden
}

Science communication efforts in the Netherlands started with exhibitions in national history museums in the 19th century and popular articles about science and technology in the media in the 1930s. From the 1950s onwards, the Dutch government stimulated popularisation of science and technology as a way to foster the science-society relationship. Democratic, and later economic and cultural considerations were the reasons for setting up oneway and two-way science communication. This may explain why attitudes towards science and technology have largely been positive compared to most other European countries, but at the same time not all new technologies are accepted. Genetic modification is an example of a topic that raised a lot of debate in the 1990s; today, opposing views on vaccination show that acceptance of science and technology is not straightforward in the Netherlands. Science communication efforts are visible in many ways in Dutch society via organisations, events and activities. These are supported or organised by both private and public partners. Nowadays, Dutch researchers are increasingly stimulated to engage with society-for instance, via the Dutch Research Agenda. Science communication in the Netherlands can build on a rich variety of expertise and inputs. 


\section{Introduction: Dutch rationales for science communication efforts}

In the Netherlands, science communication followed in the footsteps of Dutch public information campaigns in the agricultural sector. Immediately after World War II, the government focused on rebuilding Dutch society. In this process, science and technology played a role based on the economic principle that whatever is right for science and technology is also right for society. Although science communication did not yet exist as a field of study and practice in the Netherlands, attention to popularisation had been growing, with the aim of acquiring societal support for science and technology (Dalderup, 2000; Dijkstra, 2008).

From the 1950s onwards, various government programs supported science communication as a way to foster the science-society relationship. The first policy report that mentioned science communication was published by the government in 1957 (see Table 25.1 below for an overview of the most prominent government reports on science and society). The Bender Commission, established by an advisory committee of collaborating universities, argued that universities should systematically improve relationships with the groups in society they depend on, and try to gain public trust. This was basic public relations, but the commission preferred the label 'science information' (in Dutch: voorlichting). A democratic rationale emerged: everyone is entitled to have access to knowledge and information and should be able to use this to discuss matters of science and technology. Consequently, at the end of the 1950s, the first science information officials—as they were called—started working at the universities. Science communication in the Netherlands was still in its infancy (Dalderup, 2000; Dijkstra, Seydel and Gutteling, 2004; Wiedenhof, 1978).

Table 25.1: Overview of reports that discussed science and its relation to society and the role for science communication.

\begin{tabular}{|l|l|}
\hline 1957 & Commission Bender \\
\hline 1974 & $\begin{array}{l}\text { Nota Wetenschapsbeleid [Report on Science Policy] by Boy Trip, the first } \\
\text { minister of Research Policy }\end{array}$ \\
\hline 1982 & Wetenschap als gemeengoed [Science as common good] by Professor Stappers \\
\hline 1984 & $\begin{array}{l}\text { Integratie van wetenschap en techniek in de samenleving [Integration of } \\
\text { science and technology in society] by Wim Deetman, Minister of Education, } \\
\text { Culture and Science }\end{array}$ \\
\hline 1990 & $\begin{array}{l}\text { Wetenschap en techniek voor een breder publiek [Science and technology } \\
\text { for all] by PWT }\end{array}$ \\
\hline 1992 & $\begin{array}{l}\text { Kabinetsstandpunt Publieksvoorlichting over wetenschap en techniek } \\
\text { [Cabinet's position on public information about science and technology] }\end{array}$ \\
\hline
\end{tabular}




\begin{tabular}{|l|l|}
\hline 2000 & $\begin{array}{l}\text { Boeiend, betrouwbaar en belangrijk [Fascinating, trustworthy and important] } \\
\text { by the Ministries of Economic Affairs, of Education, and of Agriculture }\end{array}$ \\
\hline 2014 & $\begin{array}{l}\text { Wetenschapsvisie 2025: keuzes voor de toekomst [Science vision 2025: } \\
\text { choices for the future] by the Minister of Education, Culture and Science }\end{array}$ \\
\hline 2019 & $\begin{array}{l}\text { Nieuwsgierig en betrokken: de waarde van Wetenschap [Curious and engaged: } \\
\text { the value of science] by the Minister of Education, Culture and Science }\end{array}$ \\
\hline
\end{tabular}

\subsection{Democratic rationales and the emergence of science shops}

Science communication efforts received a boost when the first Minister of Research Policy, Boy Trip, took office in 1973. His report on research policy, Nota Wetenschapsbeleid (Trip, 1975), discussed extensively the background of both research policy and science communication. According to the minister, the pursuit of scholarly work should not take place (or be considered) separate from its societal context. Researchers should strive to come in close contact with the actors concerned. The minister believed that, in this way, the public would be able to develop their own opinions about scientific research, and public participation would be improved. In 1978, as a result of the report, the Office of Science Information was established. It championed the principle that citizens have the right to know and understand (Dijkstra, 2008; Stappers et al., 1983).

In the 1970s, when government influence on science and technology policy was strong, the first science shops were created at the universities. The concept originated in the Netherlands, and the first shops were run by students on a voluntary basis with support from employees. They were set up after debates on research policy concluded that universities should play a more prominent role in the solution of societal problems. They were based on democratic grounds, with a goal of supporting groups that could not afford to commission research (such as oppressed minorities and financially weak groups). From 1978 onwards, science shops received financial support from the universities (Lürsen, Mulder and Lieshout, 2000).

By about 2000, most universities hosted science shops, with the number peaking at 33. However, a few years later, several shops had to close as the universities stopped funding them. These funding cuts resulted from a combination of the economic downturn and a shift in policy as universities no longer considered societal support so important. Only a handful of science shops still exist in the Netherlands, but, interestingly, the concept has gained international support and can be found in universities all over the world (De Bok and Mulder, 2004; Lürsen et al., 2000; Mulder and Straver, 2015). 


\subsection{Economic rationales for science communication}

At the beginning of the 1980s, several public debates emerged spontaneously in Dutch society, on topics such as nuclear energy and the environment. At the same time, in 1984, Minister of Education, Culture and Science Wim Deetman released a new policy report called Integratie van wetenschap en techniek in de samenleving [Integration of science and technology in society]. Key themes included the dissemination of information, the development of public opinion and social decision-making. The minister stated that it was necessary to intensify and diversify information dissemination efforts and that the public needed continuous science information to be able to follow developments. The economic rationale for science information started playing a more dominant role. Scientific as well as technological knowledge is considered indispensable for achieving economic progress.

Two new organisations were established in 1986 to enhance information dissemination efforts. The first, the Foundation for Public Information on Science and Technology (PWT, later the Dutch Science and Technology Association) replaced the Office of Science Information and dealt with informing the public about science and technology (Wiedenhof, 1995). The second organisation, the Netherlands Organisation for Technology Assessment (NOTA, renamed the Rathenau Institute in 1994) was commissioned to study societal and ethical aspects of science and technology, to inform policymakers about the outcomes, and to stimulate public debate about new developments. These tasks were partly inspired by the experiences from the US Office of Technology Assessment (Tuininga, 2000).

Five years later, in 1989, Minister Deetman again advocated the strengthening of public support for science and technology. He thought that fostering scientific literacy through increasing knowledge was important, since developments were moving so quickly that the gap between science and societal groups was widening. New initiatives such as the Science and Technology Week were organised and encouraged. From 1993, a series of six public debates on biotechnology topics were organised or commissioned by the government to raise public support for biotechnology. These culminated with a debate on genetically modified (GM) food in 2001 (Dijkstra, 2008). Activities were no longer organised solely on the basis of democratic or economic rationales-there is a growing awareness that science and technology are inherently connected to society. A cultural perspective entered Dutch thinking about the science-society relationship (Dalderup, 2000). 
In his evaluation in 1995 of 10 years of science information campaigns, Wiedenhof concluded that the economic rationale had become more influential, but that democratic as well as cultural rationales also played a role. According to him, these rationales are one of the reasons why science information activities in the Netherlands were doing well compared to developments abroad (Wiedenhof, 1995, 2000). But in the following years, changes occurred as the government interfered in science communication more often-as science information had been renamed then to emphasise the change towards two-way transactions and dialogue - and demanded immediate and clear evidence of attitudinal effects. Science communication efforts were also aimed at science education, and the Dutch Science and Technology Association was dismantled in 2007. Dalderup (2000) considered that the economic rationale had become dominant by the beginning of the 21 st century, as democratic or cultural motives for science communication were relegated to the background (cf. Dijkstra, 2007).

\subsection{A more reluctant government}

For many years a conservative government has been in office in the Netherlands, and it has been reluctant to stimulate science communication as it is not considered a core responsibility, particularly in light of the 2008 economic crisis. Economic profits have been the main drivers for science, technology and innovation, and, consequently, for science communication or public engagement. Despite this stance towards science communication, a few government initiatives are worth mentioning. In 2010, the government commissioned a societal debate about nanotechnology to tackle the public's experiences with biotechnology; in 2014, it started working on the so-called Dutch National Research Agenda, where priorities are driven by societal needs. In addition, universities started reconsidering their relationship with society.

A public debate about nanotechnology was organised in 2010 and 2011. Taking into account criticisms that an earlier debate on GM food in 2001 was biased in favour of GM products, this time a more bottom-up public engagement approach was used. The lesson learned from previous experience was that a societal dialogue should feed into decision-making. The responsible committee organised the societal dialogue in two phases, with the first aiming to provide essential information as not many people had heard of nanotechnology before, and the second phase aiming to establish a dialogue (Krabbenborg and Mulder, 2015). In practice, however, an evaluation of the activities arranged by the various organisations and selected and funded by the committee concluded that activities mainly focused on outreach and knowledge transfer, and that this was a missed opportunity for genuine dialogue and bottom-up approaches (Krabbenborg and Mulder, 2015). 
Recently, the exercise on the Dutch National Research Agenda ${ }^{1}$ has been relevant for science communication in the Netherlands. And, although the process has not yet been evaluated for its implications, it still can be considered an interesting example of a bottom-up approach aiming to include societal needs in research. In 2014, the government decided to ask Dutch citizens what research questions they considered important. The aim was to establish a Dutch National Research Agenda for the future, as outlined in a new policy report on science and its role in society (Ministerie Van OCW, 2014). The promise was that the responses would be taken seriously, and a budget would be allocated in a later phase to address these societal questions. The rationale was to connect science to society in a better way.

Everyone was quite surprised when about 12,000 questions were submitted, mainly by citizens - but representatives of various interest groups including researchers also handed in questions. Under the guidance of university professors, in the next step 25 so-called main 'routes' containing research areas were identified, which included 140 research questions to be addressed-for example, about climate change and sustainability. Meetings and deliberations with citizens were organised to discuss the questions and what researchers could or should do to answer them. In 2018, calls for large multidisciplinary research proposals were made available for researchers, with funding of $€ 70$ million. As a follow up in 2019, the Minister of Education, Culture and Science published a new policy report Nieuwsgierig en betrokken: de waarde van wetenschap [Curious and engaged: the value of science], which included a budget increase for the Dutch Research Agenda to $€ 130$ million from 2020 onwards (Ministerie Van OCW, 2019). In addition, the minister specifically allocated $€ 1$ million for science communication, for a pilot program to be organised by the Dutch Research Organisation to reward researchers who engage in dialogue with society. According to the policy report, the reasoning is that everyone should benefit from scientific findings, and these can be achieved by better connecting science to society-hence the emphasis on engaged researchers (Ministerie Van OCW, 2019).

At the same time (and independently from government efforts), Dutch universities have been reconsidering their relationship with society and are acknowledging that societal needs should be better incorporated in their research and policies. Following the example of the UK, some universities established offices of public engagement. This aligned with thinking about the science-society relationship in the wider world in which science communication is one aspect next to, for instance, science education, gender

1 See www.wetenschapsagenda.nl/?lang=en. 
and ethics. These, including further engagement and open access, are also propagated at the EU level as guiding principles for responsible research and innovation.

To sum up, policies and their rationales have played a significant role in the Dutch science-society relationship and have strongly influenced efforts for science communication until the beginning of the 2000s. The next section discusses Dutch attitudes towards science and technology as well as towards specific technologies.

\section{Attitudes towards science and technology in the Netherlands}

In the Netherlands, public perceptions and attitudes towards science and technology have not been measured often. In 2000, the Social and Cultural Planning Office (SCP) and the Netherlands Organisation for Scientific Research (NWO) conducted a survey with 1,777 interviews (Becker and Van Rooijen, 2001). Respondents considered science trustworthy and prestigious and there was optimism about the ability of science to solve contemporary problems. Science and technology were both evaluated and the results were similar: both were considered good and beneficial for society (Becker and Van Rooijen, 2001). Five years later, in 2005, a Special Eurobarometer survey (Eurobarometer, 2005) showed that 97 per cent of the Dutch agreed that 'science and technology developments will help cure illnesses such as AIDs or cancer'. This was the highest rate in the EU. As well, 70 per cent agreed that 'science and technology make our lives healthier, easier and more comfortable'. Compared to other EU countries, the Dutch responses have been among the most positive in Europe, with approval levels similar to those of Sweden and Denmark.

This optimism had also been visible in attitudes towards biotechnology and related topics in the 1980s and 1990s (Gutteling et al., 2001). A more negative shift in media coverage occurring in countries such as Germany and the UK, in response to the birth of Dolly the cloned sheep and the marketing of GM soybeans by US-based agrochemical company Monsanto, did not occur in the Netherlands, as Einsiedel et al. (2002) pointed out. The Dutch government had invited the public to consider the risks of new technologies relatively early, when they commissioned six public debates on topics such as Herman the Bull (the world's first transgenic bovine born in 1990) and GM organisms for food applications. Despite these debates, however, in the 1990s and 2000s attitudes towards biotechnology gradually became more negative (but not as negative as in other countries) (Dijkstra, 2008). 
The most recent Eurobarometer (2014) showed again that Dutch believe that science and technology innovation will have a positive impact. The Dutch perceptions ( 84 per cent) were the most positive, followed again by Sweden (83 per cent) and Denmark (82 per cent). Recent studies conducted when the public debate about nanotechnology was organised also showed positive attitudes towards this emerging technology, albeit for a specific audience that showed interest in science (cf. Dijkstra and Critchley, 2016). Finally, a recent study by Hanssen et al. (2018) found that Dutch attitudes towards genetic modification or genetically modified organisms are neutral, neither in favour of nor against the technology. Dutch attitudes are complex and related to general attitudes toward science and technology and to different aspects of trust. One conclusion from the studies was that the Dutch show a more active and engaged behaviour when their direct personal interests are involved.

\section{How is science communication institutionalised in the Netherlands?}

The previous sections considered the rationale for science communication efforts focusing on policies and government influence, and then described Dutch attitudes towards science and technology. Now we look at the way science communication has been institutionalised and is visible in organisations, events or education in the Netherlands. (See the timeline at the end of the chapter for an overview of significant science communication events and activities in the Netherlands.)

\subsection{Museums and media}

The first places in the Netherlands where science and technology were available for a broader audience were the natural science and history of science museums. The National Museum for Natural History opened in Leiden in 1820 , long before any other similar institution. Several other museums opened their doors at the beginning of the 20th century. In 1904 the National Sciences Museum (renamed Museon) started its exhibitions in The Hague; in 1923, the Museum of Labour opened in Amsterdam. It subsequently went through several name changes before settling on NEMO Science Museum in 2016. In Leiden, the National Museum Boerhaave opened in 1928; it started with a series of interactive exhibits in the 1980s (Van Mensch, 2000).

Media reported on science early. The Dutch popular journal Natuur \& Techniek [Science \& Technology] has featured articles about science and technology since the 1930s. More science reporting emerged in newspapers, radio and television in the 1960s. A highlight is the reporting of the Apollo landing 
on the moon in 1969. Two reporters-Henk Terlingen, better known as mad-Henkie, and Chriet Titulaer-became well known for their enthusiastic broadcast of the landing (Dalderup, 2000). In 1966 the first television program showed The Young Researchers' Competition (Dalderup, 2000). However, for a long time, science communication on television was not considered important. Dalderup (2000) explains that in the year 1978/79 the total number of hours related to science communication was 10 hours out of a total of 3,000 hours, while in the neighbouring country Belgium this was 110 out of 2,800 hours.

In 1969, a separate Chapter of Science Journalism was created as part of the Netherlands Journalism Organisation. The conference 'Science in Journalism' in 1978 discussed the active role of journalism in science and technology, and the first science sections appeared in Dutch newspapers in 1981 (Volkskrant) and 1982 (NRC). In 1985 the Chapter on Science Journalism became the independent Association for Science Journalism in the Netherlands (VWN). However, as in other countries, times changed for science journalists, and in 2013 it was recognised that science communication had developed into a task that now also involved science journalists, and the name was changed to the Association for Science Journalism and Communication Netherlands. It had become almost impossible for science journalists to earn their income as independent journalists only.

The Dutch non-academic journal Tijdschrift Wetenschap, Techniek en Samenleving [Journal for Science, Technology and Society] provided a more reflective view on the science and society relationship from 1997 until 2005. It examined the relationship between science, technology and society, from the perspectives of both science communication and science and technology studies. Its readers were based in universities and government bodies. Until 2011 it continued as the Yearbook Knowledge Society, with its discussions focusing on a different societal theme each year, such as developments in surveillance and privacy issues.

\subsection{Science centres and events}

In the period 1960 to 1980 , many other activities were initiated, including setting up the first science centre Evoluon by the company Philips in Eindhoven in 1966. The company wanted to show how science and technology, and mechanics and computerisation, lifted production levels with humanising technologies. The centre demonstrated how technology can solve societal problems. The first exhibition was a success, but the centre was not viable financially. It is noteworthy that Evoluon opened before the Exploratorium in the US, although it never served as an example for other science centres as the latter did (Van Mensch, 2000). 
In 1986 the Dutch government commissioned advice about a National Centre for Science and Technology. Several proposals competed for the national centre, but the final report in 1987 was quite a surprise: the government decided that it would not fund a national centre. In 1989 there was another blow, when Philips decided not to proceed with the Cosmocentre Project as a replacement for the ageing Evoluon. Some of the original proposals for the national centre decided to further their plans anyway.

There were further discussions and a new plan was developed, also for a centre in Amsterdam. In 1992 the Ministers of Economic Affairs and Education and Science supported this plan, with promises of assistance from the city and industry. In 1997 NewMetropolis opened its doors in a building designed by the world-famous architect Renzo Piano. Unfortunately, the expenses were such that the museum suffered huge financial losses from the beginning. Therefore, in 1999, a restart was made as the science centre NEMO, later NEMO Science Museum, which is increasingly paying attention to science and hands-on activities (Van Mensch, 2000). Nowadays, NEMO is the bestknown science museum in the Netherlands.

The creation of science centres and media coverage of science were complemented by setting up the first national science week. It was organised at the University of Utrecht in 1986 with funding from the national government. The next year, the Dutch Science Week Association, funded by the Ministry of Education (and later with additional funding from the Ministry of Economic Affairs) started organising an annual science week. The event had its ups and downs until it was discontinued in 2007. Currently, a smaller event takes place (without much government funding) to coincide with the European Science Night.

\subsection{Science communication in other places}

At the beginning of the 2000s, the liberal government gradually retracted most of its funding for science communication in the Netherlands, and activities and events started being organised by non-government actors. From 2010 onwards, for example, several music festivals in the Netherlands offer science lectures and demonstrations as well as music. The Zwarte Cross festival, a huge event, provides a whole tent to university researchers where they give lectures and demonstrations to festival participants who are willing to broaden their interest as well enjoy the music.

Another activity gaining ground in the Netherlands is the science café, with the first organised in Nijmegen in 2005. The organisers came across a cafe scientifique in France when their car broke down and they had to wait for 
repairs. The formula was an immediate success, and, by 2016, about 15 to 20 science cafés were successfully organised on a regular basis. Most of them are run by volunteers and free of charge and several are in cities where there is no university (Dijkstra, 2017).

\subsection{From courses to master's programs and science communication research}

Another outcome of science policy developments in the 1970s was the funding and development of courses in science communication, with the first ones starting in 1976. Jaap Willems, a biologist and former journalist, taught one in Nijmegen. He was the first PhD graduate in the field in the Netherlands and defended his thesis on science journalism and communication barriers in the same year (Willems and De Bekker, 1976). Only a handful of PhD students have graduated in science communication topics in the Netherlands. Niels Wiedenhof completed his thesis in 1978 on the development of science communication in the Netherlands, while more than 20 years later in 1999, Adriana Esmeijer analysed selection processes in science journalism (Wiedenhof, 1978; Esmeijer, 1999). The next batch of three PhD theses was defended in 2008 (Dijkstra, 2008; Van der Auweraert, 2008; Van der Sanden, 2008). Since then a handful of others have completed their theses.

Over this period the number of science communication educational programs at universities has risen slowly. At the end of the 1990s, the Minister of Education, Culture and Sciences announced that the general universities should offer science students the possibility of a track in science communication, science education or science management. This would fulfil societal needs, and the general universities in the Netherlands responded by developing science communication programs. In 2006, the technical universities successfully applied for science communication programs for their engineering students, and these started in 2007. At this moment, next to several single courses or modules, a science communication specialisation at the master's level is offered by about half the Dutch universities.

Research in science communication is conducted mainly at the universities that offer educational programs. Topics of research vary widely and are often connected to either the focus areas of these programs, the various backgrounds of the researchers involved, or externally funded projects in which the scholars participate. For instance, not only is the interaction between scientists and audiences studied, but research projects may also examine the role for scientists in the process of innovation (Van der Sanden and Flipse, 2016). 


\section{Organisational capacities}

The Netherlands has always been a country where citizens organise themselves in associations. Most Dutch citizens are members of five or more associations either professionally, privately or on a voluntary or paid basis; and this holds for the Dutch science communication field as well (Riedlinger et al., 2018). The VWN exists as well as the association for public information officers (PWC). In 2013, SciComNL started, connecting practitioners in science communication with a 'community of practice' approach so that they could learn from each other.

National conferences for science communicators were organised soon after courses at universities were developed. Beginning at the end of the 1990s, the Dutch Science and Technology Association organised a few conferences to further knowledge about science communication, but never on a structural basis. Nowadays, with other partners, NEMO organises an annual Science Communication in Practice conference that attracts about 200 participants, mostly practitioners. Science communication students organise an annual student conference for all students in one of the Dutch programs. And last but not least, in 2022, Rotterdam will host the first PCST conference to be held in the Netherlands. This will be a collaborative effort of all universities and other organisations in the Netherlands involved in science communication.

\subsection{Science communication in the Netherlands varies richly}

The thinking on science communication as well as its practices are continuously changing in the Netherlands. Starting in the 19th century when the first natural history museum opened, the Dutch government was an important stimulator of science and society interactions. For a long time, science communication was considered a task of keeping the Dutch public informed. However, from the first policy report onwards, improving relationships between science and society by gaining public trust and making science available for everyone was an important driver for starting and stimulating efforts and providing funding. Many science communication efforts were established between the 1970 s (when the first information officers started working at the universities) and the 1990s. Universities, as the case of the science shops has shown, played a prominent role in these activities. When governmental commitment became less prominent, other organisations slowly took over. Events such as promoting science and technology at music festivals have been funded by private parties, while science cafés offering more in-depth discussion of the newest scientific developments are mainly run by volunteers. In a more 
recent trend, the Dutch Research Agenda shows more government support for communication and demands that researchers play a more active role engaging in science communication.

\section{Conclusion}

When it comes to controversial topics, the Dutch start organising themselves sooner or later, as exemplified by the first spontaneous public debates on nuclear energy and the environment. Dutch citizens are becoming increasingly aware that science and technology are influencing our society, and the evidence lies in the many discussions in the public domain on topics such as privacy, climate change and robots. At the same time, citizens have to deal with new developments such as fake news or the trustworthiness of science. In recent years, Dutch citizens seem to engage more regularly in science-related activities, not only as receivers of information but also as active participants in scientific research. At home, in science centres and in informal education, they have engaged in and contributed to activities within the scientific process. In the Netherlands, these activities vary from regular participation by birdwatchers in bird population research to citizens who bring up questions about the living environment and team up with a university to become involved in research projects (see European Citizen Science Association, 2015). However, there is always tension, and despite memberships of associations and citizen science contributions, active engagement is often restricted to a few topics and to certain (often higher educated) publics.

Practices of science communication in the Netherlands are continuously changing. As this chapter shows, science communication practices started out mainly by informing people about science. The approach today is more inclusive and varied, as illustrated by the views of one prominent practitioner reported below.

\section{Box 25.1: Changing practices from the perspective of a science communicator}

Jac Niessen (1955) works for Wageningen University \& Research (WUR) as the science information officer. His main task is to connect the media and the public at large with the experts at his university, as well as guiding scientific results towards the media. After his biology degree, he started as a science journalist for the popular magazines Natuur en Techniek and Bionieuws, and the agricultural magazine Landbouwkundig Tijdschrift. As science communicator for the science funding agency (NWO), he was an editorial board member for the annual national science quiz for Dutch TV. 
He feels that over the years, the practice of science communication has changed substantially. Niessen has observed a shift from content to formats. Social media in particular has caused this shift: it is no longer about the story itself but more about the way it is told, who says what and to whom. The implication is that science communicators (like Niessen) do more with less content.

Before the age of social media, media coverage of announcements contained in press releases was the main medium for communicating about science. Communication was aimed at large audiences, such as those who read newspapers or watch TV. Nowadays, someone approaches the university with a question and that person receives an answer quickly, coming directly from an expert. On a daily basis, Niessen and his colleagues monitor what happens in society to find out what stories or developments dominate (social) media. They may then decide to publish a dossier on the topic, appoint an expert as spokesperson and use social media to attract attention. This approach has strongly accelerated communication, as well as the recycling of information.

Another major shift is the movement from transmission to dialogue. Debating issues as they are will mainly cause polarisation, according to Niessen. Instead, with the help of communicators, scientists engage in dialogue, and both parties may acquire better understanding of the various opinions.

In recent years, trust in public institutes such as universities has decreased. Now a story told by a person outside the university can often do a better job, and with more credibility, than a story told by a university researcher. For this reason, the university regularly asks prominent alumni to serve as ambassadors, who then may be asked if they are willing to use their networks on specific issues.

According to Niessen, the speed of communication will further increase in the future. Response times will come down and audiences will become smaller, perhaps in the end to a single individual.

\section{References}

Becker, J. W. and van Rooijen, P. M. (2001). Het beeld van de wetenschap in Nederland. Opvattingen van de bevolking, wetenschappers, adviseurs en Kamerleden in 2000. Den Haag: SCP/NWO.

Dalderup, L. (2000). Wetenschapsvoorlichting en wetenschapsbeleid in Nederland 1950-2000. Gewina: Tijdschrift voor de Geschiedenis der Geneeskunde, Natuurwetenschappen, Wiskunde en Techniek, 23, 165-92.

De Bok, C. and Mulder, H. (2004). Wetenschapswinkels in de kennissamenleving. Tijdschrift voor Hoger Onderwijs, 22, 123-39.

Dijkstra, A. M. (2007). Perspectief op het democratisch motief in de wetenschapscommunicatie. In J. Willems (ed.), Basisboekwetenschapscommunicatie. Amsterdam: Boom Onderwijs.

Dijkstra, A. M. (2008). Of publics and science. How publics engage with biotechnology and genomics (PhD thesis). University of Twente. 
Dijkstra, A. M. (2017). Analysing Dutch Science Cafés to better understand the science-society relationship. Journal of Science Communication, 16(01), A03, 1-17. doi.org/10.22323/2.16010203.

Dijkstra, A. M. and Critchley, C. R. (2016). Nanotechnology in Dutch science cafés: Public risk perceptions contextualised. Public Understanding of Science, 25, 71-87. doi.org/10.1177/0963662514528080.

Dijkstra, A. M., Seydel, E.R. and Gutteling, J. M. (2004). Effectieve wetenschapscommunicatie: een communicatievraagstuk. Kennisdagen Communicatie 2003. Effectieve publiekscommunicatie: hints voor de Wetenschapsen techniekcommunicatie. Papers, positiepapers en tips. Amsterdam: Stichting Weten.

Einsiedel, E., Allansdottir, A. et al. (2002). Brave new sheep - the clone named Dolly. In M. W. Bauer and G. Gaskell (eds), Biotechnology. The Making of a Global Controversy (pp. 313-47). London: Cambridge University Press.

Esmeijer, A. (1999). Sluiswachters in de wetenschapscommunicatie. Een studie naar selectieprocessen bij het populariseren van (alfa)onderzoek. Amsterdam, Vrije Universiteit.

Eurobarometer. (2005). Special Eurobarometer 224 'Europeans, Science \& Technology'. European Commission.

Eurobarometer. (2014). Special Eurobarometer 419 'Public perceptions of science, research and innovation'. European Commission.

European Citizen Science Association. (2015). Ten principles of citizen science. London: European Citizen Science Association.

Gutteling, J., Midden, C., Smink, C. and Meijders, A. (2001). The Netherlands: controversy or consensus? In G. Gaskell and Martin W. Bauer (ed.), Biotechnology 1996-2000. The years of controversy (pp. 229-36). London: Science Museum.

Hanssen, L., Dijkstra, A. M., Sleenhoff, S., Frewer, L. J. and Gutteling, J. M. (2018). Revisiting public debate on Genetic Modification and Genetically Modified Organisms. Explanations for contemporary Dutch public attitudes. JCOM, 17(04), A01. doi.org/10.22323/2.17040201.

KoninklijkeNederlandseAcademievan Wetenschappen. (1977). Wetenschapsvoorlichting. Rapport over de instelling van een dienst wetenschapsvoorlichting. Amsterdam: Koninklijke Nederlandse Academie van Wetenschappen.

Krabbenborg, L. and Mulder, H. A. J. (2015). Upstream public engagement in nanotechnology: Constraints and opportunities. Science Communication, 37, 452-84. doi.org/10.1177/1075547015588601.

Lürsen, M., Mulder, H. and Lieshout, M. (2000). Kronkelpaden en afslagen; ontwikkelingen in en om wetenschapswinkels. Gewina: Tijdschrift voor Geschiedenis der Geneeskunde, Natuurwetenschappen, Wiskunde en Techniek, 23, 207-13. 
Ministerie Van OCW. (2014). Wetenschapsvisies 2025: keuzes voor de toekomst. Den Haag, Ministerie van Onderwijs, Cultuur en Wetenschap.

Ministerie Van OCW. (2019). Nieuwsgierig en betrokken: de waarde van wetenschap. Den Haag, Ministerie van Onderwijs, Cultuur en Wetenschap.

Mulder, H. and Straver, G. (2015). Strengthening community-university research partnerships: Science shops in the Netherlands. In B. Hall, R. Tandon and C. Tremblay (eds), Strengthening community university research Partnerships: Global perspectives (pp. 181-96). Victoria, British Columbia: University of Victoria and PRIA.

Riedlinger, M., Barata, G., Van der Sanden, M., Medvecky, F. and Joubert, M. (2018). PCST roundtable: The role of professional science communication associations in supporting science communicators and legitimising communication practices. Proceedings 15th International Public Communication of Science and Technology Conference, Dunedin, New Zealand, 2018.

Stappers, J. G., Reijnders, A. D., Möller, W. A. J. and Hesp, L. A. T. M. (1983). Wetenschap als gemeengoed. Een studie van de wetenschapsvoorlichting in Nederland. 's Gravenhage, Staatsuitgeverij.

Trip, F. H. P. (1975). Nota wetenschapsbeleid. 's-Gravenhage: Tweede Kamer, zitting.

Tuininga, E.-J. (2000). Sturing van wetenschap en technologie, 1965-2000. Gewina: Tijdschrift voor de Geschiedenis der Geneeskunde, Natuurwetenschappen, Wiskunde en Techniek, 23, 58-71.

Van der Auweraert, A. (2008). De onderzoeker als communicator. Een kwalitatief en verkennend onderzoek naar de determinanten van wetenschapscommunicatiegedrag (PhD thesis). Wageningen University and Research Centre.

Van der Sanden, M. (2008). Towards effective biomedical science communication (PhD thesis). Free University Amsterdam.

Van der Sanden, M. C. A. and Flipse, S. (2016). Science communication for uncertain science and innovation, Journal of Science Communication, 15(06), C05. doi.org/ $10.22323 / 2.15060305$.

Van Mensch, P. (2000). Tussen object en samenleving: 25 jaar musea van natuurwetenschap en techniek in Nederland. Gewina: Tijdschrift voor de Geschiedenis der Geneeskunde, Natuurwetenschappen, Wiskunde en Techniek, 23, 193-206.

Wiedenhof, N. (1978). Wetenschapsvoorlichting: een bijdrage tot beeld-, oordeels-en besluitvorming. Eindhoven, Technische Hogeschool Eindhoven.

Wiedenhof, N. (1995). Aarde, appel, ei -Wetenschaps- en techniekvoorlichting in Nederland en ook wat daarbuiten. 1985-1995. Utrecht, Stichting PWT. 
Wiedenhof, N. (2000). Wetenschaps- en techniekvoorlichting op zoek naar balans tussen Apollo en Dionysus. Gewina: Tijdschrift voor de Geschiedenis der Geneeskunde, Natuurwetenschappen, Wiskunde en Techniek, 23, 228-39.

Willems, J. and De Bekker, J. (1976). Wetenschapsjournalistiek: klachten en communicatiebarrières. Nijmegen: Universiteit Nijmegen.

\section{Timeline}

\begin{tabular}{|c|c|c|c|}
\hline Event & Name & Date & Comment \\
\hline $\begin{array}{l}\text { First interactive science } \\
\text { centre. }\end{array}$ & $\begin{array}{l}\text { Evoluon, set up by } \\
\text { the company Philips } \\
\text { in Eindhoven }\end{array}$ & 1966 & $\begin{array}{l}\text { Aimed to demonstrate how } \\
\text { science and technology can } \\
\text { solve societal problems }\end{array}$ \\
\hline $\begin{array}{l}\text { First national (or large } \\
\text { regional) science } \\
\text { festival. }\end{array}$ & & $\begin{array}{l}\text { Since } \\
2000\end{array}$ & $\begin{array}{l}\text { Presence at science festivals, } \\
\text { later also at music festivals }\end{array}$ \\
\hline $\begin{array}{l}\text { An association of } \\
\text { science writers } \\
\text { or journalists or } \\
\text { communicators } \\
\text { established. }\end{array}$ & $\begin{array}{l}\text { Chapter of science } \\
\text { journalists created } \\
\text { in the Netherlands } \\
\text { Journalism } \\
\text { Organisation }\end{array}$ & 1969 & $\begin{array}{l}\text { 1985: The chapter becomes } \\
\text { the independent Association } \\
\text { for Science Journalism (WWN) }\end{array}$ \\
\hline $\begin{array}{l}\text { First university courses } \\
\text { to train science } \\
\text { communicators. }\end{array}$ & $\begin{array}{l}\text { Science journalism } \\
\text { courses }\end{array}$ & 1976 & $\begin{array}{l}\text { Offered by Jaap Willems, } \\
\text { for example }\end{array}$ \\
\hline $\begin{array}{l}\text { First master's } \\
\text { students in science } \\
\text { communication } \\
\text { graduate. }\end{array}$ & & $\begin{array}{l}\text { Since } \\
2000\end{array}$ & $\begin{array}{l}\text { Universities offer science } \\
\text { communication programs } \\
\text { after request by minister }\end{array}$ \\
\hline $\begin{array}{l}\text { First PhD students in } \\
\text { science communication } \\
\text { graduate. }\end{array}$ & Jaap Willems & 1976 & $\begin{array}{l}\text { 1978: Niels Wiedenhof } \\
\text { 1999: Adriana Esmeijer }\end{array}$ \\
\hline $\begin{array}{l}\text { First national } \\
\text { conference in science } \\
\text { communication. }\end{array}$ & $\begin{array}{l}\text { Organised by } \\
\text { Stichting WeTeN } \\
\text { [Association for } \\
\text { Science and } \\
\text { Technology } \\
\text { Netherlands] }\end{array}$ & 1990s & $\begin{array}{l}\text { 2013: Annual Vakconferentie } \\
\text { Wetenschapscommunicatie } \\
\text { [Science communication } \\
\text { conference for professionals] } \\
\text { organised by NEMO other } \\
\text { partners }\end{array}$ \\
\hline $\begin{array}{l}\text { National government } \\
\text { program to support } \\
\text { science communication } \\
\text { established. }\end{array}$ & Commission Bender & 1957 & $\begin{array}{l}\text { Universities should } \\
\text { strengthen their relationship } \\
\text { with society }\end{array}$ \\
\hline $\begin{array}{l}\text { First significant initiative } \\
\text { or report on science } \\
\text { communication. }\end{array}$ & $\begin{array}{l}\text { Nota } \\
\text { Wetenschapsbeleid } \\
\text { [Report on Science } \\
\text { Policy] }\end{array}$ & 1975 & $\begin{array}{l}\text { By Boy Trip, the first minister } \\
\text { of research policy }\end{array}$ \\
\hline $\begin{array}{l}\text { National Science Week } \\
\text { founded. }\end{array}$ & & 1987 & $\begin{array}{l}\text { 1986: the first regional } \\
\text { Science Week in Utrecht }\end{array}$ \\
\hline
\end{tabular}




\begin{tabular}{|c|c|c|c|}
\hline Event & Name & Date & Comment \\
\hline $\begin{array}{l}\text { A journal completely } \\
\text { or substantially } \\
\text { devoted to science } \\
\text { communication } \\
\text { established. }\end{array}$ & $\begin{array}{l}\text { Tijdschrift } \\
\text { Wetenschap, Techniek } \\
\text { en Samenleving } \\
\text { [Journal for Science, } \\
\text { Technology and } \\
\text { Society] }\end{array}$ & $\begin{array}{l}1997- \\
2005 \\
(2011)\end{array}$ & $\begin{array}{l}\text { Followed up by the Jaarboek } \\
\text { Kennissamenleving [Yearbook } \\
\text { Knowledge society]. Both } \\
\text { non-academic journals } \\
\text { dedicated to science, } \\
\text { technology and society and } \\
\text { science communication }\end{array}$ \\
\hline $\begin{array}{l}\text { First significant radio } \\
\text { programs on science. }\end{array}$ & Various programs & $1960 s$ & $\begin{array}{l}\text { A highlight is the radio } \\
\text { reporting on the moon } \\
\text { landing in } 1969\end{array}$ \\
\hline $\begin{array}{l}\text { First significant TV } \\
\text { programs on science. }\end{array}$ & $\begin{array}{l}\text { The Young } \\
\text { Researchers } \\
\text { competition }\end{array}$ & 1966 & \\
\hline $\begin{array}{l}\text { First awards for } \\
\text { scientists or journalists } \\
\text { or others for science } \\
\text { communication. }\end{array}$ & $\begin{array}{l}\text { Various prizes and } \\
\text { awards }\end{array}$ & $\begin{array}{l}1990 s \\
\text { to } \\
2000 s\end{array}$ & $\begin{array}{l}\text { 2009: Boy Trip Fonds [Boy } \\
\text { Trip Fund/NWN Trip Fund] for } \\
\text { science journalists }\end{array}$ \\
\hline $\begin{array}{l}\text { Date hosted a PCST } \\
\text { conference. }\end{array}$ & $\begin{array}{l}\text { PCST conference will } \\
\text { be hosted in } 2023\end{array}$ & 2023 & \\
\hline \multirow[t]{4}{*}{$\begin{array}{l}\text { Other significant } \\
\text { events. }\end{array}$} & $\begin{array}{l}\text { The popular } \\
\text { journal Natuur \& } \\
\text { Techniek [Science \& } \\
\text { Technology] }\end{array}$ & 1930s & $\begin{array}{l}\text { More science reporting } \\
\text { emerges in the second half } \\
\text { of } 1960 \text { s; in newspapers, on } \\
\text { radio and television }\end{array}$ \\
\hline & $\begin{array}{l}\text { First science shops } \\
\text { emerge }\end{array}$ & $1970 s$ & $\begin{array}{l}\text { Science shops originated in } \\
\text { the Netherlands, with the first } \\
\text { run on a voluntary base }\end{array}$ \\
\hline & $\begin{array}{l}\text { Platform Wetenschap } \\
\text { Communicatoren } \\
\text { [Association for Public } \\
\text { Information Officers] } \\
\text { formed }\end{array}$ & $\begin{array}{l}\text { End of } \\
1980 \text { s }\end{array}$ & $\begin{array}{l}\text { Science communicators start } \\
\text { organising themselves in } \\
\text { various professional groups. } \\
\text { 2013: ScicomNL network } \\
\text { starts building a Community } \\
\text { of Practice }\end{array}$ \\
\hline & $\begin{array}{l}\text { First science café } \\
\text { Nijmegen }\end{array}$ & $\begin{array}{l}\text { Since } \\
2005\end{array}$ & $\begin{array}{l}\text { 2016: } 15-20 \text { science cafés in } \\
\text { various cities are organised } \\
\text { on a regular basis }\end{array}$ \\
\hline
\end{tabular}

\section{Contributors}

Dr Anne M. Dijkstra is an assistant professor in science communication at the University of Twente.

Frans van Dam lectures on science communication and writing and presentation skills at Utrecht University, The Netherlands.

Dr Maarten van der Sanden is an associate professor of Communication Design for Innovation at TU Delft, Department of Science Education and Communication. 
This text is taken from Communicating Science: A Global Perspective, edited by Toss Gascoigne, Bernard Schiele, Joan Leach, Michelle Riedlinger, Bruce V. Lewenstein, Luisa Massarani and Peter Broks, published 2020 by ANU Press, The Australian National University, Canberra, Australia.

doi.org/10.22459/CS.2020.25 